\title{
Communication value of displays and postures in Red-vented Bulbul Pycnonotus cafer (Aves: Pycnonotidae)
}

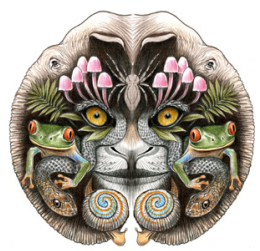

\author{
Anil Kumar \\ Arunachal Pradesh Regional Centre, Zoological Survey of India, Itanagar, Arunachal Pradesh 791113, India \\ Email: anil_rathi@yahoo.com
}

Abstract: I investigated visual signals mediated through displays and postures and their importance in communication in Red-vented Bulbul Pycnonotus cafer. Observations revealed that this species used five types (namely mate acquisition display, greeting display, alarm display, crest position and begging display) of visual signals for communication and showed three types of sleeping postures and broken-wing display. Mate acquisition display was performed to maintain pair bond and when two individuals met, one of them would use greeting display along with low amplitude complex vocalisations. The position of the crest seemed to vary with different behavioural contexts; it was raised erect in alarm and recumbent during greeting. Nestlings/ fledglings used specific begging displays that included gaping with or without vocal signals. The presence of a predator in close vicinity of bird/nesting site, elicited alarm displays along with alarm calls. The present study revealed that the displays and postures are important means of communication under various social contexts and were often accompanied with vocalisations thus making them multi-component. It is believed that the multi-component signals provide more reliable information for receivers and increase the efficacy of communication.

Keywords: Avian communication, displays, pair bond, postures, Pycnonotus cafer, Red-vented Bulbul, vocalisation.

Date of publication (online): 26 June 2010 Date of publication (print): 26 June 2010 ISSN $0974-7907$ (online) | 0974-7893 (print)

Editor: Aziz Aslan

Manuscript details:

Ms \# 02272

Received 29 July 2009

Final revised received 09 May 2010

Finally accepted 18 May 2010

Citation: Kumar, A. (2010). Communication value of displays and postures in Red-vented Bulbul Pycnonotus cafer (Aves: Pycnonotidae). Journal of Threatened Taxa 2(6): 919-929.

Copyright: (c) Anil Kumar 2010. Creative Commons Attribution 3.0 Unported License. JoTT allows unrestricted use of this article in any medium for non-profit purposes, reproduction and distribution by providing adequate credit to the authors and the source of publication.

Author Details: Dr. ANIL KUMAR is an avian biologist. For last five years he is working as a scientist in Zoological Survey of India (ZSI). After completion of five years at ZSI, Itanagar, Arunachal Pradesh, recently he is shifted to ZSI, Solan, Himachal Pradesh. Over the years his research work is focused on behavioural ecology and sociobiology of birds with specia interest to their communication systems. $\mathrm{He}$ is an Antarctican also.

Acknowledgements: See end of this article.

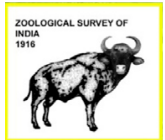

(c) (1) (口)

OPEN ACGESS | FREE DOWNLOAD

\section{INTRODUCTION}

Birds convey information to each other mainly in visual and vocal modalities. In many avian species, often these two occur simultaneously, while in some others, visual displays and postures are used in the absence of vocal signals (Bright 1984; Butcher \& Rohwer 1989; Murphy 2006; Randler 2007). The visual signals constitute specific movements of head, body, wings and tails, which are often enhanced by elaborate plumage and patches of coloured feathers (Marler \& Hamilton 1966; Birkhead 1991; Fitzpatrick 1999; Randler 2006). Most avian species use threat displays in conflict with conspecific/heterospecific over valuable resources such as territory, food and mates (Birkhead 1991). The head-up posture has been reported in fighting and territorial defense in passerine birds (Marler 1961). Threat displays of most avian species involve postures in which the head, bill and wings are often directed maximally towards the opponent (Andrew 1961; Birkhead 1991). Many visual signals are partially or entirely concerned with mate acquisition and are usually known as courtship/mating displays. Extravagant feather ornaments and phaneric colouration of plumage are also used to synchronise the reproductive process and mate acquisition in birds (Bradbury \& Vehrencamp 1998; Cuervo \& Moller 1999; Fusani et al. 2007).

When signals are highly extravagant with combinations of visual and acoustic elements, they are known as 'multi-component' (Rowe 1999) or 'multimodal' signals (Guilford \& Dawkins 1991; Rowe \& Guilford 1999). There are many examples, where avian species used multi-component signals in their communication, such as sexual displays (Frith 1981; Petrie et al. 1991; Zuk et al. 1992), warning signals (Lange \& Leimar 2003), aggressive displays (Deag \& Scott 1999; Hurd \& Enquist 2001), and begging signals (Kilner et al. 1999; Dickens et al. 2008). It is believed, that multi-component signals provide more reliable information for receivers, and are better received than a single signal alone (Rowe 1999; Leonard et al. 2003). However, in certain situations, the use of unimodal signals is more beneficial for the signaler and receiver both, in terms of cost of signal (Alcock 2001).

In the Indian context, our knowledge of displays and postures is scanty 
and based on observations on natural history made by Dr. Salim Ali. Later, a few studies were also made by Ali's students, colleagues and some others (Kumar \& Bhatt 2001). Crook (1963) documented the displays related to mate acquisition and territory advertisement in two species of weaver birds. The components of upright wings beating display in Streaked Weaver Ploceus manyar and upright wings rigid display in Black-throated Weaver $P$. benghalensis were described. Some displays such as wing undulating display, high speed wing beating and female solicitation posture were also described in Finn's Weaver P. megharhynchus (Ali \& Crook 1959). Ali \& Ripley (1983) made preliminary natural history notes on displays, postures and associated behaviour in some Indian birds. Arial displays in the Lesser Florican Sypheotides indica were studied by Sankaran (1996a). $\mathrm{He}$ quantitatively described the territorial displays of Bengal Florican Houbaropsis bengalensis also (Sankaran 1996b). Bhatt \& Kumar (2001) characterised the types of visual signals and their importance in the sociobiology of Oriental Magpie Robin Copsychus saularis. Gadagkar (2003) reviewed and highlighted the significance of Indian Peafowl Pavo cristatus as an icon of sexual selection in modern studies. In the present article, I have described the displays, postures with context of use in Red-vented Bulbul Pycnonotus cafer for the first time.

\section{MATERIAL AND METHODS}

Pycnonotus is the largest genus in the bulbul family Pycnonotidae represented by having 36 species (Myers et al. 2008). Red-vented Bulbul Pycnonotus cafer is widely distributed throughout the Indian subcontinent. It is a perky smoky-brown avian species with a partially crested black head, scale-like markings on breast and back, a conspicuous crimson patch below the root of the tail and a white rump, the last particularly noticeable in flight. It is a resident species, inhabitant of gardens and light scrub forest, both near and away from human habitation. It is an arboreal, non-territorial (individuals do not defend territories), sexually alike species, lives in pairs to large flocks (Vijayan 1978; Ali \& Ripley 1983).

The present investigation was carried out in three phases from January 1996 to December 1999, March 2002 to February 2005 and April 2005 to July 2007. During the first phase, field observations were made on 38 individuals, in and around Gurukul Kangri University campus, Haridwar (29055'N \& 7808'E), Uttarakhand (Image 1). The habitat of the area was sub-urbanised composed of small gardens, tree patches, shrubs, hedges, open grass fields and fragmented agriculture fields. Data was collected by visiting three different study sites (within $12 \mathrm{~km}^{2}$ area) periodically, once or twice a week as per requirement, between early morning and late evening. Usually, the behaviour of the target birds was observed with the help of $7 \times 50$ binoculars. In some cases, displays and postures were recorded with the help of a SONY handycam video camera and a Pentax still photography camera with tele-lens $(300-600 \mathrm{~mm})$. For determining the behavioural context of information revealed by the signals, the social circumstances in which signaling occurred were examined. The characteristics and elements of different displays were defined analyzing the video films and still photographs. For the measurement of elevation of crest, a horizontal line ( $A$ to $B$ ) was drawn over the proximal end of upper mandible and the centre of the eye (Fig. 1). One vertical line ( $D$ to $C$ ) passing through the centre of the eye and the apex of the crest was laid on a horizontal line. The angle CDB was highest (up to $105^{\circ}$ ) during crestup position and lowest (up to 0 to $5^{\circ}$ ) during crest-down position. Hence, the degree of angle was positively corelated with the elevation/ erection of crest feathers, so the degree of angle (CDB) was measured to measure the elevation of the crest. Angle CDB was measured with the help of still photographs/videos (in still mode) and behavioural correlates were observed in the field. In some cases, the degree of angle was directly inferred through the binoculars, while observing the behaviour of target individuals. In case of multi-component signals, the vocalizations combined with displays were recorded using Sony PCM-M1 or Marantz PMD 222 sound recorders and JVC MZ-500 or Sennheiser ME-66 microphones. Recordings were digitized using M-Audiophile 2496 (data acquisition card) at a sampling rate of 24 to $48 \mathrm{kHz}$ and 16-bit resolution. High quality recordings were analyzed with the help of Avisoft SASLab Pro (version 4.40). Spectrograms were produced with the following settings: 512 FFT-length; 75\% Frame; Flat Top window and 87.5\% time window overlap.

During the second phase, the observations were made on 29 individuals in Doon Valley (Image 1), adopting the same methodology (except videography) as in the first phase. The main study site was the Wildlife Institute of India (WII) campus, Dehradun and adjacent areas $\left(30^{\circ} 26^{\prime} \mathrm{N} \& 78^{\circ} 06^{\prime} \mathrm{E}\right)$. Some observations were also made in the Zoological Survey of India (ZSI) campus, Indian Institute of Remote Sensing (IIRS) campus and the lower hills of Mussoorie. All sites were within a 30 $\mathrm{km}$ radius. The habitat of the main study site was suburbanised, composed of residential settlements, gardens, planted trees and shrubs. In the third phase, opportunistic observations were made on 12 individuals in and around

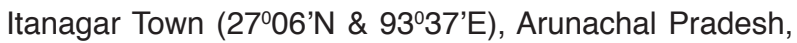
adopting the same methodology except videography and photography. 


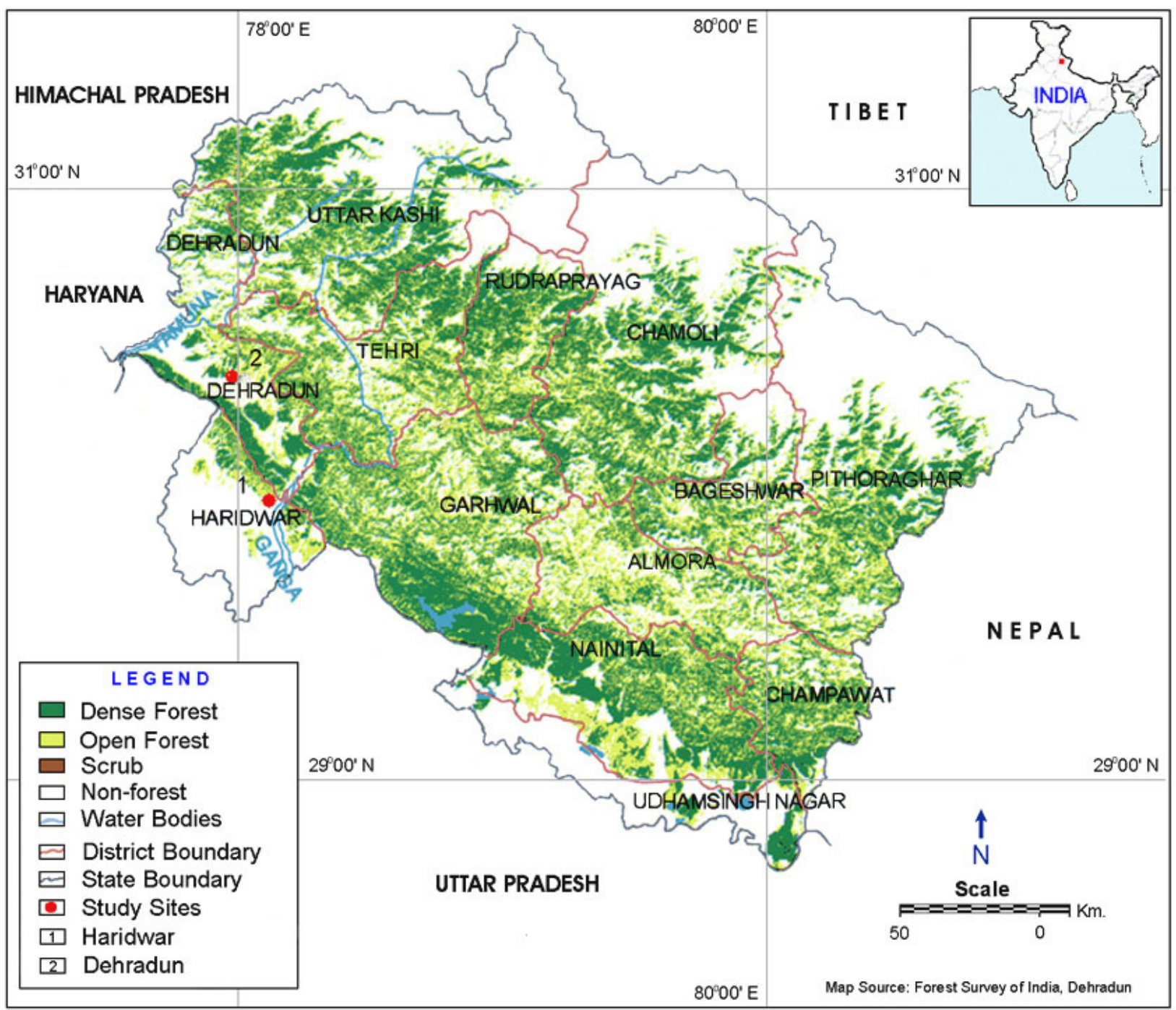

Image 1. Map of the Uttarakhand state is showing the main study sites.

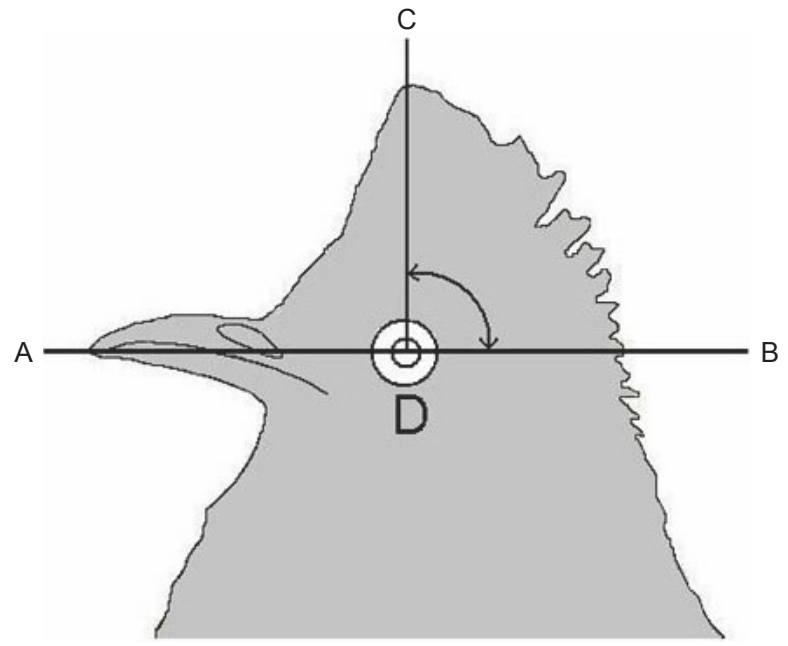

Figure 1. Measurement of elevation of crest in Red-vented Bulbul.

\section{RESULTS}

\section{Mate Acquisition Display}

It is a dance display in which one of the sexes dances near an individual of the opposite sex. This display was observed in breeding as well as in non-breeding seasons, most probably to maintain pair bond. However, the display was observed mostly in birds that were in pairs (94\% cases; $n=128)$. This display was performed mainly during morning and evening hours and lasted from 1.5 to 3 minutes. In most cases $(78 \% ; n=128)$ the display was repeated 3-7 times at a stretch. The elements of display were: one bird would approach its mate and spread its tail fully; then it would move its body left and right flicking its wings simultaneously in slow motion. It would then lower its head and stretch its neck and body in front of its mate (Image 2). During the display, red coloured feathers of the vent were also fluffed, erected and exposed, so that the opposite sex could see them. However, the crest often remained low. After the 


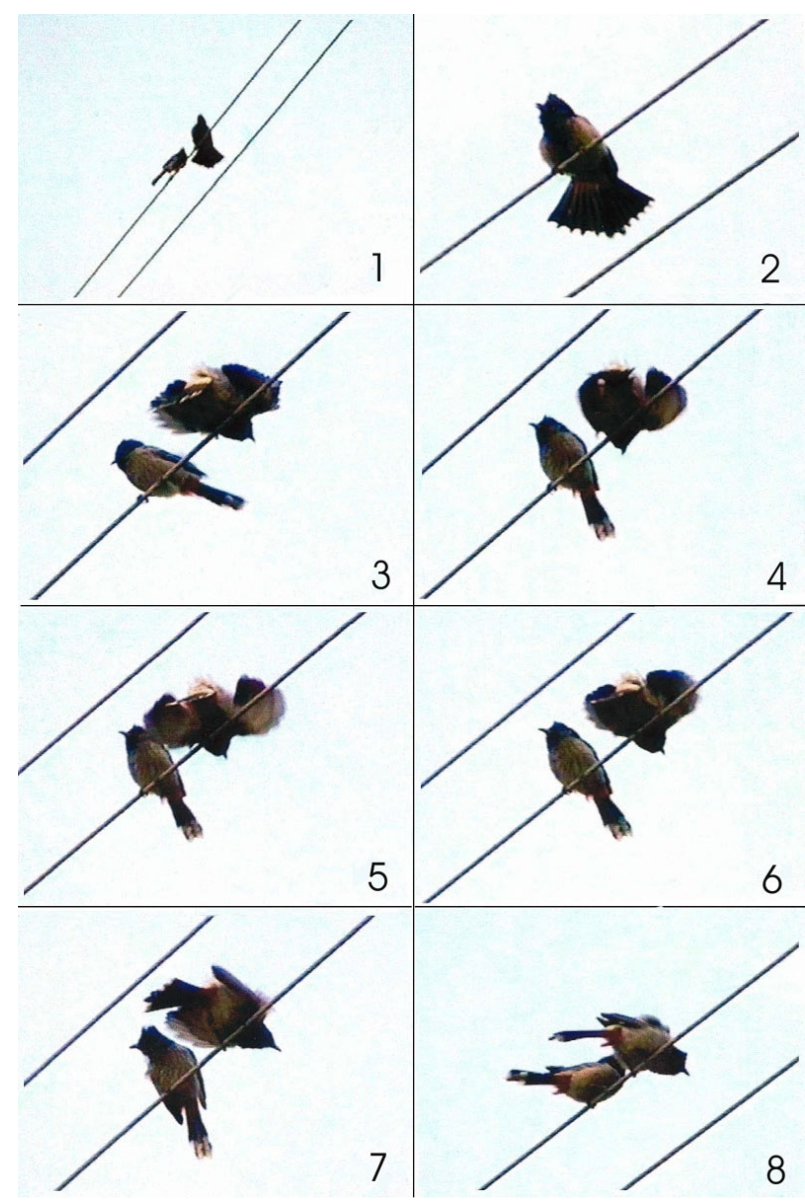

Image 2. Sequential components and structural elements (1 to 8) of Mate Acquisition Display in Red-vented Bulbul.

display, both sexes were often ( $86 \%$ cases) engaged in allopreening. This behaviour would end in mating in the breeding season if the female was receptive. Usually, the dancing bird emitted low-amplitude, complex, frequency modulated vocalisations (Fig. 2) during this display. The vocalisations recorded during this behaviour, were soft, continuous, low-amplitude, complex and most probably opposite sex oriented. These were composed of a number of song phrases (P-1 to $\mathrm{P}-8)$ with irregular phrase gaps such as between P-5, P-6 and P-7, and repetition of phrases (P-6 and P-7) was also observed (Fig. 2). Sometimes, individuals produced phrases made up of a single element phrase, such as P-2 in Fig. 2, and comparatively narrow band, short and complex elements (when compared to the regular structure of elements, such as in P-1) with irregular phrase gaps, i.e., P-2, P-3 and P-4. Often two phrases (such as P-6 and P-7) with the lowest gap constitute a large phrase-complex. These phrases were composed of 2 to 6 types of elements. The average minimum frequency, maximum frequency and range of frequencies were $0.92 \pm 0.03(n=28), 3.29 \pm 0.04$ $(n=28)$ and $2.12 \pm 0.04(n=30) k H z$, respectively. The average duration of phrases was $0.26 \pm 0.02 \sec (n=36)$ and followed by $0.33 \pm 0.05 \mathrm{sec}(n=36)$ gap.

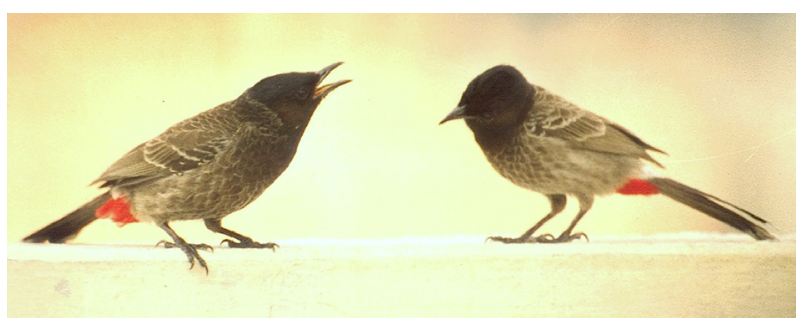

Image 3. A pair of Red-vented Bulbuls performing Greeting Display.

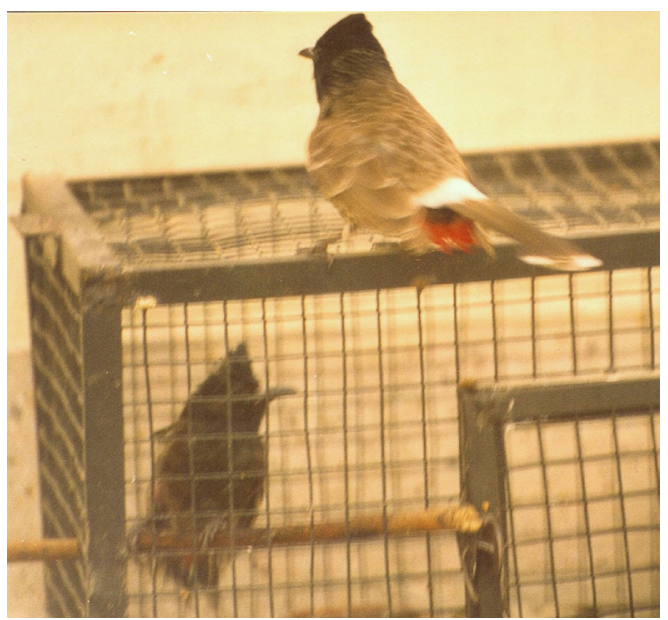

Image 4. Display of red-vent feathers during Greeting Display.

\section{Greeting Display}

The red coloured feathers of the vent of this bird were observed erected and fluffed out during social interactions. When two individuals met, they often showed their crimson patch to each other (Image 3). While doing so they erected and fluffed the red patch-feathers. Generally the red patch remained under the tail feathers, which was cryptic in nature. However, it was noticed that the red patch display was not used in every social interaction and by every member of the foraging/wintering flocks. This display was used by birds irrespective of the time of the day and the seasons of the year. In some cases, the bird raised both wings upwards with or without utterance of greeting calls (Kumar 2004).

In an experiment, when the cage of a Red-vented Bulbul was kept in an open area, another bulbul came and both were observed greeting each other, displaying their red patch (Image 4) and they also produced soft, complex and frequency modulated vocalizations (Fig. 3). These signals were low pitched, narrow band, low amplitude vocalizations. Acoustical analysis revealed that these signals were composed of song phrases (such as P-1 to P-8 in Fig. 3) having almost dissimilar structured elements. Individuals used 1 to 4 phrases in a bout composed of either similar or dissimilar structured elements. Phrase-complex (two or more phrases without inter phrase gap) was also observed. This behaviour was 


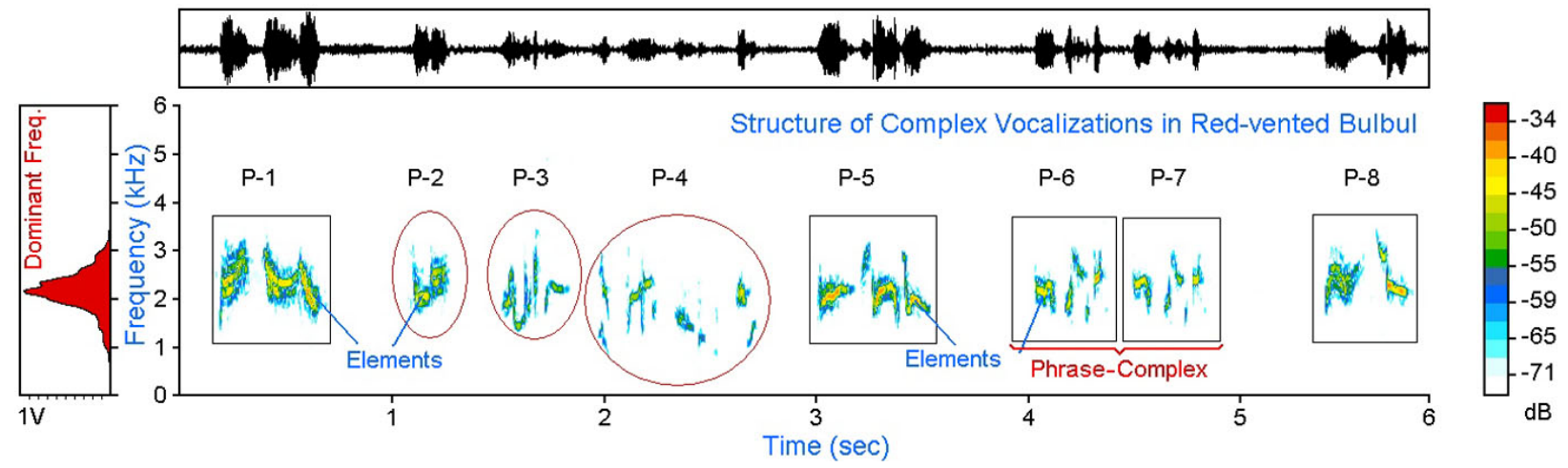

Figure 2. Spectrograms of complex vocalizations produced by Red-vented Bulbul during Mate Acquisition Display.

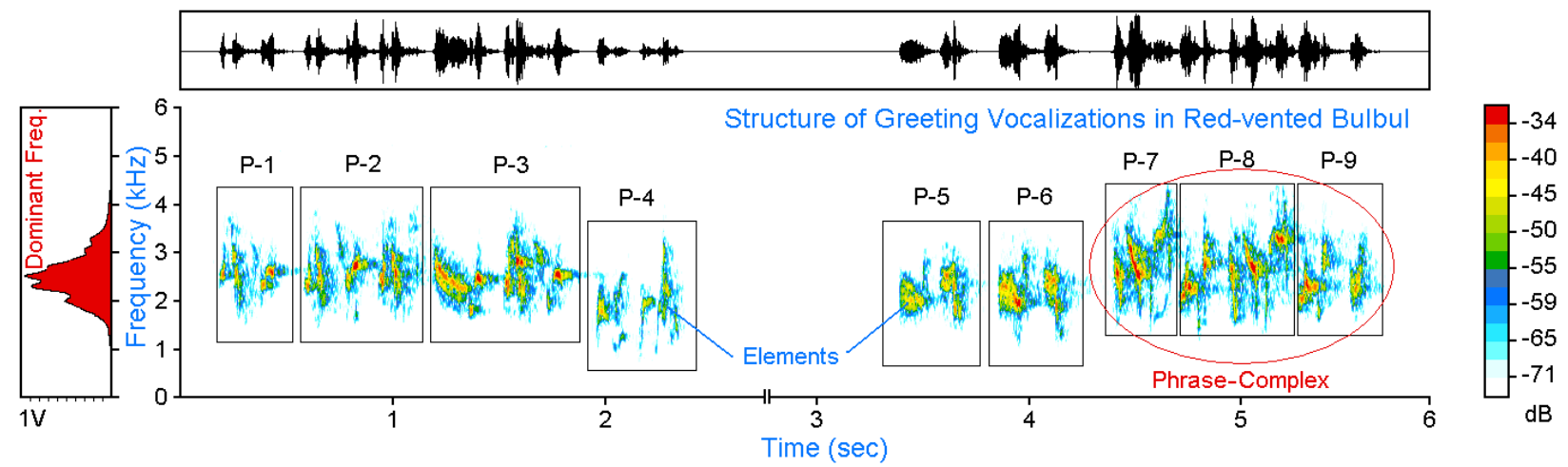

Figure 3. Physical characteristics and structure of vocalizations produced during Greeting Display.

observed many times and thus, it can be inferred that birds use this display to greet each other.

\section{Alarm Display}

Whenever a predator (viz. Shikra Accipiter badius, Eurasian Sparrow Hawk A. nisus, Asian Barred Owlet Glaucidium cuculoides, Spotted Owlet Athene brama, Rufous Treepie Dendrocitta vagabunda, Grey Treepie D. formosae and Crested Serpent Eagle Spilornis cheela etc.) was observed by a Red-vented Bulbul within a distance of $130 \pm 9 \mathrm{~m}(\mathrm{n}=30)$, it performed a specific left-right action of its head and body with the help of its wings, one left-right scan took about a second. The rate of left-right movement was observed to increase when a predator approached the bird or nesting site. During this display the bird also uttered alarm calls (Kumar 2004). A careful observation of this posture further revealed that this display indeed increased the visual zone of the bird as compared to the normal position. It was assumed that in the normal position the bird can see about $275^{\circ}$ to $300^{\circ}$

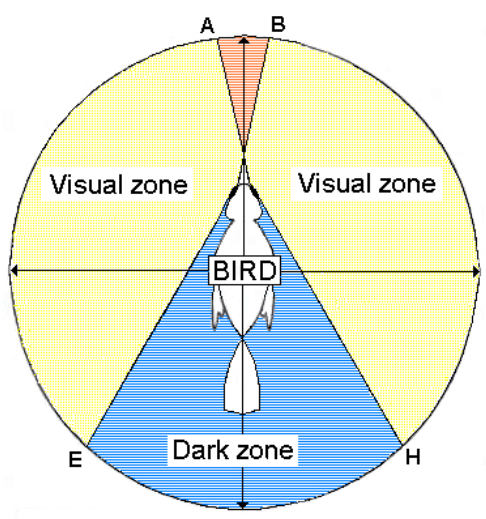

A - Normal position

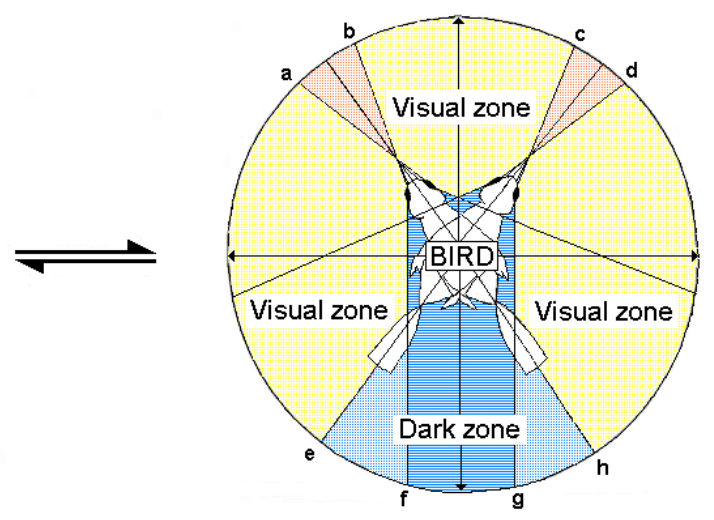

B - Display position

Figure 4. Diagrammatic presentation of tentative visual and dark zone in Red-vented Bulbul.

[A] In normal position bird can scan approx. $275^{\circ}$ to $300^{\circ}$ ( $\mathrm{E} \mathrm{to} \mathrm{H}$, clockwise) including zone of binocular vision (A to B). [B] During the display, cyclopean area increased about $300^{\circ}$ to $340^{\circ}$ ( $\mathrm{f}$ to $\mathrm{g}$, clockwise) and blind/dark zone decreased approx. $60^{\circ}$ (e to $\mathrm{h}$, anticlockwise) to $20^{\circ}$ approx (f to $\mathrm{g}$, anticlockwise). The zone of binocular vision approx. $30^{\circ}$ ( $\mathrm{A}$ to $\mathrm{B}$ ) also increased about $60^{\circ}$ more ( $\mathrm{b}$ to c, clockwise). 
zone (Fernandez-Juricic et al. 2004; Martin 2007), while this display facilitated the bird to see about $300^{\circ}$ to $340^{\circ}$ area per scan thus increasing visual acuity and visual zone enormously (Fig. 4). Probably the increased zone helped the bird to watch predator's movements constantly, and the movement of its wings kept it ready to escape, in case of approach of the predator.

\section{Crest Position}

In this species, the crest is of moderate size $(9.24 \pm 0.48$ $\mathrm{mm}, \mathrm{n}=16$ ) present in both sexes and has a movable group of crown feathers. The degree of the angle between the anterior edge of the crest and the horizontal plane of the head varied according to circumstances (Table 1). The angle between crest and head (with few exceptions) seemed to be positively correlated with the degree of excitement $\backslash$ danger. The crest was at a higher level of erection (about $85-90^{\circ}$ ) during the presence of a predator in the close vicinity of the bird/ nesting site. It reached the highest level of erection (approx. 105 ${ }^{\circ}$ ) when the bird was about to be captured or was captured by the predator. Often, captured individuals uttered distress calls also (Kumar 2004). During social contacts (through vocalizations) the crest position was highly varied (between $35^{\circ}$ and $80^{\circ}$ ), while, during mate acquisition, sleeping and submissive behaviour, it was at a lower level $\left(<10^{\circ}\right)$. During foraging and resting (just after foraging), individuals exhibited a slightly higher level of crest (between 10-35) (Image 5A-C).

\section{Sleeping Postures}

Three types of sleeping postures viz. Neck Shrinking Posture (NSP), Neck Turning Posture (NTP) and Neck Hanging Posture (NHP) were observed in this species. NTP was the most preferred posture during sleep (63.3\%) as compared to NSP (27.2\%) and NHP (9.4\%) out of 338 observations. During this posture, the bird turned its neck backward and tucked/concealed its beak in feathers near its shoulder (scapula feathers) in such a way that the shape of the bird was deformed and predators could not easily recognise the bird due to its cryptic appearance. During NHP, the bird simply dropped its neck and head downwards, while in NSP, the bird shrunk the neck and kept the bill pointing forwards. Both of these postures had the quality of deforming the shape of the bird and thereby protecting the bird from predators during sleep.
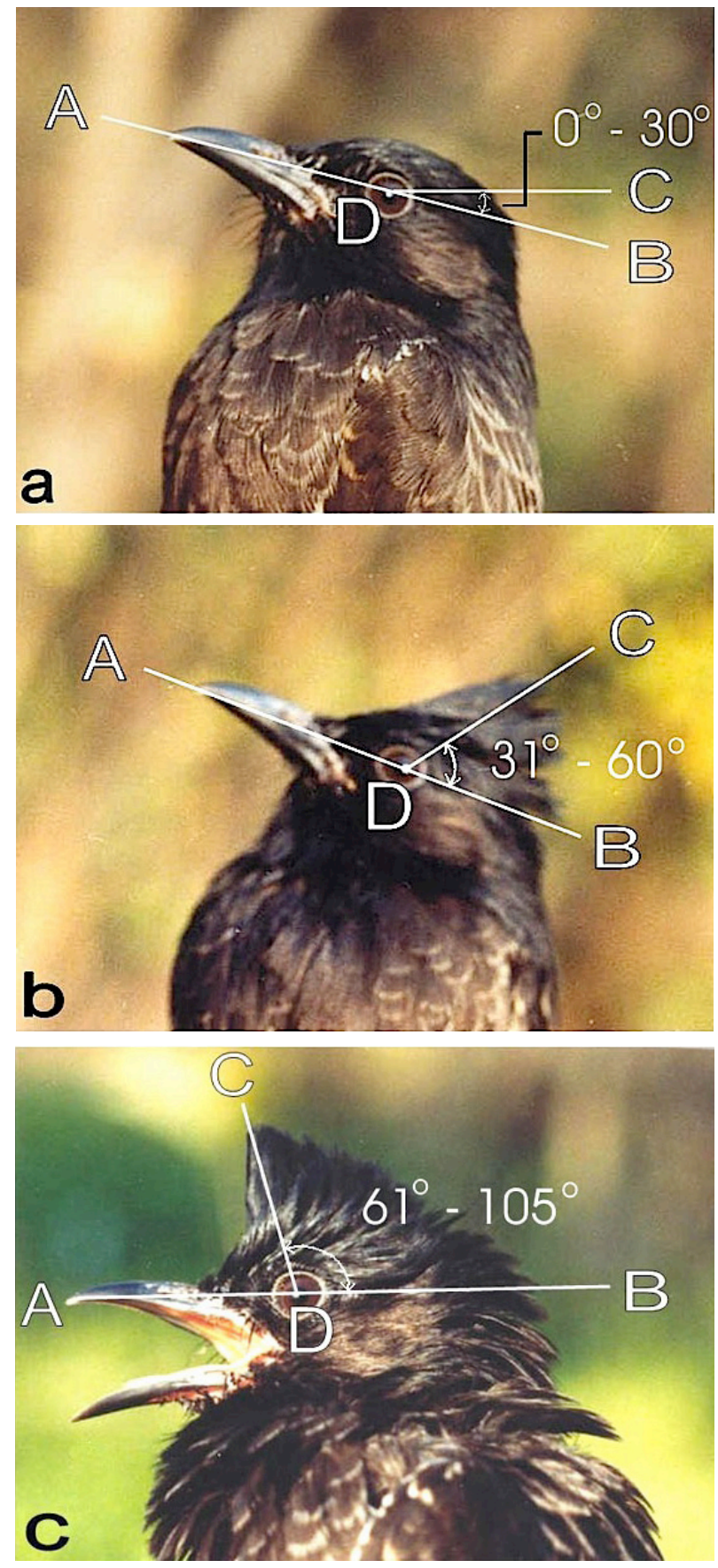

Image 5. Showing the different levels of crest and corresponding range of angle of elevation, (a) Downcrest position, (b) Middle-crest position, and (c) Up-crest position.

Table 1. Showing different levels of the crest and circumstances in which these used.

\begin{tabular}{|l|l|c|c|c|l|}
\hline & Crest Position & $\begin{array}{c}\text { Number of scan/ } \\
\text { observations }\end{array}$ & Proportion & $\begin{array}{c}\text { Crest position } \\
\text { angle }\end{array}$ & Circumstances in which used \\
\hline 1. & Down crest position & 163 & $44.9 \%$ & $0^{\circ}-30^{\circ}$ & $\begin{array}{l}\text { Greeting, begging, sleeping, feeding, egestion, } \\
\text { beak cleaning, and water drinking. }\end{array}$ \\
\hline 2. & Middle crest position & 114 & $31.4 \%$ & $31^{\circ}$ to $60^{\circ}$ & Feeding, nest guarding and preening. \\
\hline 3. & Up crest position & 86 & $23.7 \%$ & $61^{\circ}$ to $105^{\circ}$ & $\begin{array}{l}\text { During alertness, play, roosting chorus, danger } \\
\text { and attacking/ aggression/ chasing }\end{array}$ \\
\hline
\end{tabular}



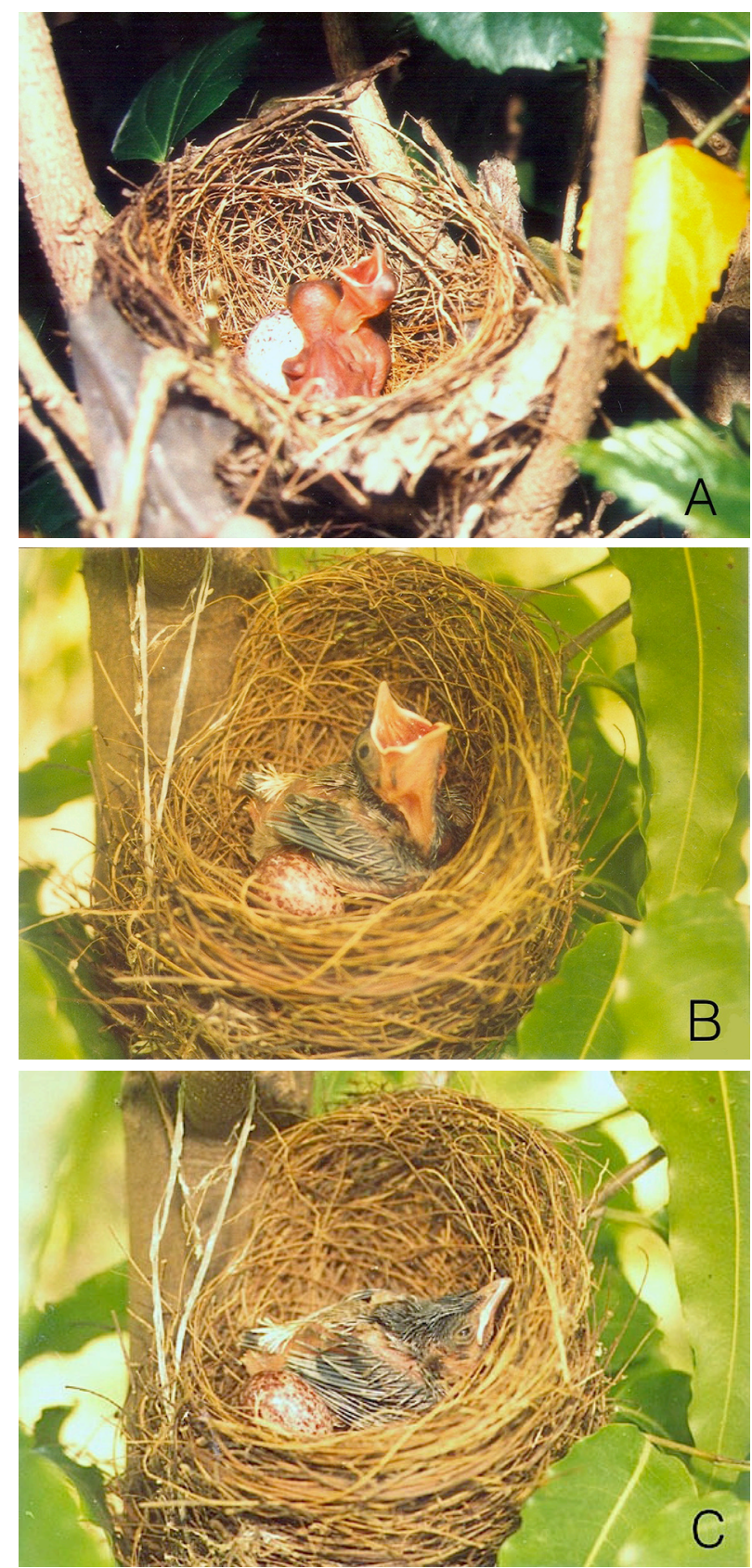

Image 6 . Begging behaviour of nestlings in Red-vented Bulbul, (A) Begging display by a hatchling, (B) Begging display by developed nestling, (C) Submissive posture of a nestling after feeling the presence of predator.

\section{Begging Display and Gaping}

The nestlings and fledglings of Red-vented Bulbul used this display frequently. On the arrival of parents at the nest, the nestlings were observed to flutter their wings, stretch their necks and gape for the food. The newly hatched nestlings (Image 6A) opened their beaks as and when they felt the presence of their parents without any vocal signals. In the early phase when their eyes remained closed the nestlings opened their beak in response to any slight jerk in the nest background. The observer's approach to the nest was enough to elicit gaping in the young. However in the later phase (after opening the eyes) they responded only to parents. Sometimes, in the absence of parents (between two feeding visits) also, they produced begging calls and/or display. When any individual other than their parents arrived at their nest, the nestlings stopped begging calls and hid themselves inside the nest and remained motionless (Images 6B \& C). In nests, where only one nestling survived, the begging displays and calls rate was very low $(0.34 \pm 0.002$ calls per visit, $n=13$ ), while, in those nests where the number of nestlings was three, the rate of displays and calls was quite high ( $15.54 \pm 0.71$ calls per visit, $n=23$ ).

The Red-vented Bulbuls used some other displays occasionally. It was observed, that when nestlings/ fledglings were approached by a predator, either of the parents used the broken-wing display. In this display, the bird would fall down on the ground and scramble forward with apparent difficulty beating its wings and producing loud distress calls continuously. This behaviour apparently would aid in distracting the attention of the predator away from the nestlings and towards the bird that feigned injury (Vijayan 1978). The moment the predator came close to the displaying bird, it would fly away. During the present study this behaviour was seen only four times.

\section{DISCUSSION}

\section{Mate Acquisition Display}

It is believed that in most temperate species pairbonds are formed for a single breeding season, while in a number of tropical birds, these bonds seem to last for life (Faaborg \& Chaplin 1984). Most avian species use either visual or vocal or both types of displays for mate acquisition. For mate acquisition, mostly male birds use various postures, display of brilliant plumage and badges (bright coloured patches). They have also been known to use undulating flights and/or spreading of tail feathers along with fascinating songs to attract a prospective mate (Welty \& Baptista 1988). In Red-vented Bulbul, such mate affection display may aid pair-bonding during non-breeding season, and may synchronise the mating process in the breeding season. Probably, this mate affection display, (which is exhibited throughout the year irrespective of breeding and non-breeding seasons), has evolved through sexual selection to maintain permanent pair bond in this species.

\section{Greeting Display}

If an animal's colouration is to function as a signal, it should be either conspicuous or distinctive (Burtt 1986). A bird like the Red-vented Bulbul may have both cryptic and conspicuous features in its feathers. It seems that its cryptic plumage of perky smoke-brown body feathers may act as protection against predators. But the bright red vent (which is normally concealed under tail feathers) 
may be used for communication at close distance such as greeting and mate acquisition.

In animals, various morphological features viz. extension of body surface, extraordinary feathers and colouration etc. are developed during the course of evolution. These specific features of the animal morphology may be ritualized and act as a sign stimuli (Marler 1961). In the social context, these sign stimuli are often known as social releasers (Krebs \& Davies 1987). It seems that in Red-vented Bulbul the red patch acts as a social releaser, which provokes the affection and closeness between two individuals. In Herring Gulls, the red spot at the tip of the parent's beak acts as a releaser. It elicits the begging behaviour in chicks. In fact, such social releasers are the basis of social communication in animals (Tinbergen \& Perdeck 1950; McFarland 1993).

\section{Alarm Display}

It is known that the eyes of most birds are aligned laterally and they can see both lateral sides in a monocular manner. The zone of monocular view of both eyes overlaps in the frontal area and forms a zone of binocular vision, which enables the bird to gather visual information more accurately as compared to monocular vision (Hart \& Lendrem 1984; Martin \& Katzir 1999; Martin \& Coetzee 2004). The posterior zone remains as a dark zone or a blind area, usually preferred by predators to approach. In birds, the visual fields have recently been categorized into three types based on degree of expansion of cyclopean area and blind area (Fernandez-Juricic et al. 2004; Martin 2009). The birds that require visual guidance to food items such as Rock Pigeon Columba livia and Starling Sturnus vulgaris can scan about $280^{\circ}$ to $300^{\circ}$ including $20^{\circ}$ to $25^{\circ}$ (approx.) binocular zone (Martin \& Young 1983; Martin 1986). The Red-vented Bulbul is also probably characterized by the same vision parameters with a scanning ability of $275^{\circ}$ to $300^{\circ}$ cyclopean area including $30^{\circ}$ (approx.) binocular zone. About $60^{\circ}$ to $80^{\circ}$ blind zone may provide enough space for predators to attack from behind. During display with a deviation about $50^{\circ}$ to $70^{\circ}$ approx. from main axis may facilitate the bird to increase the cyclopean area significantly, which possibly helps the bird to watch the predator's movement more accurately. Increased visual acuity most probably helps the bird to judge the distance of the predator during the display due to increased binocular zone.

The vision in birds has evolved due to selection pressure aroused from social communication, foraging and predation (Møller \& Erritzøe 2010). Studies show that in passerine birds, wide lateral fields of vision are not only helpful in efficient foraging but also allow detection of approaching predators (Fernandez-Juricic et al. 2004; Martin 2007). It was suggested that predation pressure in addition to efficient foraging may independently affect the position of eyes, cyclopean area of vision and blind area (Fernandez-Juricic et al. 2004). Recently, it has been reported that in birds, eye size has evolved in response to changing predator environments (Møller \& Erritzøe 2010). It is believed that large eyes capture information more accurately than small eyes, but require more brain space for information processing. It was suggested that eye size may act as a constraint on optimal anti-predator behaviour (Møller \& Erritzøe 2010). Sol et al. (2002) reported that species with relatively larger brains and higher frequency of foraging innovations tended to have a higher probability of invasion success than species with smaller brains and a lower frequency of innovations. This study revealed, that the Red-vented Bulbul was an unsuccessful invader (Sol et al. 2002). It is inferred that in the Red-vented Bulbul the brain size (and most probably eye size also) is not large. The adoption of alarm display in this species may possibly help the individuals to optimize anti-predatory behaviour, thus advantageous for successful survival.

This display has not only intra-specific but interspecific signal value also. A number of avian species viz. Jungle Babbler Turdoides striatus, Grey-breasted Prinia Prinia hodgsonii, Ashy Prinia Prinia socialis, Black Drongo Dicrurus macrocercus, Coppersmith Barbet Megalaima haemacephala, House Sparrow Passer domesticus, Common Tailorbird Orthotomus sutorius, and a mammal Five-striped Squirrel Funambulus pennantii etc. respond to this display and join Red-vented Bulbul in its alarm calls/ mobbing calls and perform visual signals to convey information regarding the presence of a predator.

\section{Crest Position}

In the present study, the crest seemed to vary in different behavioural contexts. It was raised during excitements (such as in danger/alarm, play, roosting chorus, and attacking/aggression) and recumbent during greeting, begging, sleeping and feeding. Like the Red-vented Bulbul, the crest is reported as an indicator of emotions and moods in the Eurasian Jay Garullus glandarius and Steller's Jay Cyanocitta stelleri (Goodwin 1956; Brown 1964). The jays are also reported to use the erected plumage and elevated crest in the presence of a predator during territorial conflicts and depressed plumage during escape drives (Goodwin 1956; Brown 1964). Whereas, in Chaffinch Fringilla coelebs erection of the crest was reported to indicate a thwarted escape drive (Hinde 1953). The role of the crest position has been reported in Royal Flycatchers (Onychorhynchus coronatus and $O$. mexicanus). These birds have large, brilliantly colored, fan-shaped crests, which are usually concealed but raised during courtship display, and intraand interspecific aggression (Graves 1990). However, it is difficult to suggest that the crest has any adaptive significance during courtship or mate acquisition in Red-vented Bulbul, as it is moderately sized without any phaneric colouration/ornamentation. If it had any significant role in mate acquisition, it should have been 
extravagant and/or colourful, such as in some avian species viz. Greater Bird-of-Paradise Paradisaea apoda, and Magnificent Bird-of-Paradise Diphlodes magnificus (Welty \& Baptista 1988).

\section{Sleeping Postures}

Review of literature reveals, that information is scanty on sleeping postures of Indian birds (Kumar \& Bhatt 2001). In the present study, the Red-vented Bulbul used three categories of sleeping postures. The characteristics and adopting patterns of these postures were almost similar as reported in Oriental Magpie Robin (Kumar \& Bhatt 2001). Despite recent research on sleep patterns, the adaptive significance of sleeping postures is poorly understood (Amlaner \& Ball 1983; Wellmann \& Downs 2009). It is suggested that sleeping postures are useful to conserve energy and to increase safety against predators. During the night, sleeping birds most probably would have possibilities to become a prey of nocturnal predators. So, cryptic coloration of feathers (such as in Red-vented Bulbul) may probably help the roosting birds to camouflage themselves in their surrounding to reduce the risk of predation. However, the distinct shape of the roosting individual still would have possibilities to attract a predator. So, the increased crypsis (ability of an organism to avoid observation) due to the deformed appearance of the body most probably decreased the risk of predation. During sleeping postures, the shape of the roosting bird looks like an almost spherical/oval, stationary object and it would be difficult for a predator to recognize/locate it in this posture. In the Red-vented Bulbul, the most preferred posture was NTP. During this posture, the bird mostly tucked its bill under scapula feathers, most probably to save heat loss through open breathing, when compared to NSP and NHP. In a previous study, Black-billed Magpie Pica pica has been reported to use such postures under freezing conditions, and it was suggested that this sleeping position would reduce heat loss, as it decreases volume/surface ratio (Reebs 1986). It seems true for the Red-vented Bulbul. Recently, Cape White-eye Zosterops virens and Malachite Sunbird Nectarinia famosa, have been reported to increase back sleep (bill tucked under or on the scapula feathers) and decrease front sleep (head and neck held stationary with bill pointing forwards) during low temperature (Wellmann \& Downs 2009).

The sleeping postures are reported in some other birds (Saunders 1979; Wellmann \& Downs 2009). In non-passerine species, such as in Hooded Crane Grus monacha, two types of sleeping postures (namely Head-tuck-sleep and Head-droop-sleep) were recorded (Masatomi 2004). The characteristics of head-tuck-sleep and head-droop-sleep postures were almost similar to NTP and NHP, respectively. Passerine birds are reported to use different types of sleeping postures (mostly back sleep and front sleep) during roosting (Amlaner \& Ball 1983; Wellmann \& Downs 2009).

\section{Begging Displays}

Most avian species frequently use multi-component complex displays in their communication. The evolution of these signals is favored by two main factors. It may increase the efficiency of communication (Rowe 1999), and may provide receivers with more reliable information about the quality or condition of the signaler (Johnstone 1996; Kilner \& Johnstone 1997). It is suggested that multi-component signals may be detected and recognised more quickly and easily than signals produced in a single modality. The begging displays of nestlings of the Redvented Bulbul are also made up of multi-component signals with visual elements that include posturing and gaping and vocal elements that include loud calls (Kumar 2004). Like the Red-vented Bulbul, nestlings and fledglings of most passerine birds beg for food by giving typical displays, consisting of gaping, posturing, presenting their brightly coloured gapes, and vocalising loudly. For example, the nestlings of Canary Serinus canaries, display deep pink mouths, the Dunnocks Prunella modularis, orange and Robins Erithacus rubecula, yellow. It has been reported (Kilner 1997) that mouth colour is a reliable signal of need in a begging nestling. The striking mouth colouration of nestlings is a component of solicitation behaviour that makes up the begging display (Kilner 1997). These displays appear to influence the distribution of food within broods (Kilner 1995; Price et al. 1996) and regulate the feeding rate to broods as a whole (Leonard \& Horn 1998; Leonard et al. 2000).

Results of this study indicate that in the Red-vented Bulbul, in nests where only one nestling survived, the begging displays and calls rate was very low as compared to the nests where the number of nestlings was three. It seems that the purpose of these displays and calls was to parents to demand food. As reported in some other avian species (Price \& Ydenberg 1995; Price et al. 1996), most begging occurs at the time of a parent's arrival at the nest. Between the feeding visits these displays were occasional, most probably due to receiving some nest back ground stimulus.

\section{CONCLUSION}

Visual displays and postures of birds are fundamentally one of their inherited behavioural traits, and play a significant role in communication under various social contexts. Closely related species exhibit quite similar behavioural acts, along with some unique speciesspecific behaviour. The documentation of such behaviors in a species is likely to be important to understand the evolution of social behaviour and communication systems. Such studies are also useful to develop and standardise the template for further behavioural studies on congeneric species. The present investigation provides base-line information on displays and postures, 
their communication value and context of production in the Red-vented Bulbul. It also opens up the scope for further studies on some intriguing questions that arise as a result of this study. For example, what is the role of redvent feathers in mate acquisition? Is it a reliable indicator of male quality? if yes, then why has it evolved in females also? Further research should also be focused upon the adaptive significance of sleeping postures in relation to ambient temperature, light, seasons and roosting sites. The present study may possibly enable more detailed studies to be carried out in future, especially on individual variations, seasonal/temporal variations in displays, and evolution of multi-component signals (such as begging and alarming signals) in Pycnonotus bulbuls in particular and other passerine birds in general.

\section{REFERENCES}

Alcock, J. (2001). Animal Behaviour: An Evolutionary Approach. Sinauer Associates, Inc. Publishers, Sunderland, Massachusetts, USA, xiii+543pp.

Ali, S. \& J.H. Crook (1959). Observations on Finn's Baya Ploceus megarhynchus Hume re-discovered in the Kumaon Terai, 1959, pp.81-100. In: Daniel, J.C. \& G.W. Ugra (eds.). Petronia: Fifty Years of Post-Independence Ornithology in India: A Centenary Dedication to Dr. Salim Ali, 1896-1996. Oxford University Press, Delhi, 2003, 386pp.

Ali, S. \& S.D. Ripley (1983). Hand Book of The Birds of India and Pakistan. Oxford University Press, Delhi, xiii+737pp.

Amlaner, C.J. \& N.J. Ball (1983). A synthesis of sleep in wild birds. Behaviour 87: 85-119.

Andrew, R.J. (1961). The displays given by passerines in courtship and reproductive fighting: A review. Ibis 103A: 315348.

Bradbury, J.W. \& S.L. Vehrencamp (1998). Principles of Animal Communication. Sunderland, Massachusetts: Sinauer, USA, xiii+882pp.

Birkhead, T. (1991). Behaviour. In: Brooke, M. \& T. Birkhead (eds.). The Cambridge Encyclopedia of Ornithology, Cambridge University Press, USA, 362pp.

Bright, M. (1984). Animal Language. British Broadcasting Corporation, London W1M 4AA., 247pp.

Brown, J.L. (1964). The integration of agonistic behaviour in the Steller's Jay Cyanocitta stelleri (Gmelin). University of California Publications in Zoology 60(4): 223-328.

Burtt, E.H. Jr. (1986). An analysis of physical, physiological, and optical aspects of avian coloration with emphasis on Wood Warblers. Ornithological Monograph (AOU) 38: 1-126.

Butcher, G.S. \& S. Rohwer (1989). The evolution of conspicous and distinctive coloration for communication in birds, $\mathrm{pp}$. 51-108. In: Power, D.M. (ed.). Current Ornithology. Vol. 6, Plenum Press, New York, USA, xi+332pp.

Crook, J.H. (1963). The Asian Weaver Birds: problem of coexistence and evolution with particular reference to behaviour. Journal of Bombay Natural History Society 60: 1-48.

Cuervo, J.J. \& A.P. Moller (1999). Ecology and evolution of extravagant feather ornaments. Journal of Evolutionary Biology 12: 986-998.

Deag, J.M. \& G.W. Scott (1999). 'Conventional' signals in avian agonistic displays: integrating theory, data and different levels of analysis. Journal of Theoretical Biology 196: 155-162.

Dickens, M., D. Berridge \& I.R. Hartley (2008). Biparental care and offspring begging strategies: hungry nestling Blue Tits move towards the father. Animal Behaviour 75: 167-174.
Faaborg, J. \& S.B. Chaplin (1984). Ornithology: An Ecological Approach. Prentice Hall, Englewood Cliffs, New Jersy, USA, $\mathrm{x}+470 \mathrm{pp}$.

Fernandez-Juricic, E., T.J. Erichsen, \& A. Kacelnik (2004). Visual perception and social foraging in birds. Trends in Ecology and Evolution 19(1): 25-31.

Fitzpatrick, S. (1999). Tail length in birds in relation to tail shape, general flight ecology and sexual selection. Journal of Evolutionary Biology 12: 49-60.

Frith, C.B. (1981). Displays of Count Raggi's Bird-of-paradise Paradisaea raggiana and congeneric species. Emu 81: 193201.

Fusani, L., M. Giordano, L.B. Day \& B.A. Schlinger (2007). High-speed video analysis reveals individual variability in the courtship displays of male Golden-collared Manakins. Ethology 113(10): 964-972.

Gadagkar, R. (2003). Is the peacock merely beautiful or also honest? Current Science 85(7): 1012-1020.

Goodwin, D. (1956). Further observations on the behaviour of the Jay Garrulus glandarius. Ibis 98: 186-219.

Graves, G.R. (1990). Function of crest displays in Royal Flycatches (Onychorhynchus). The Condor 92: 522-524.

Guilford, T. \& M.S. Dawkins (1991). Receiver psychology and the evolution of animals. Animal Behaviour 42: 1-14.

Hart, A. \& D.W. Lendrem (1984). Vigilance and scanning patterns in birds. Animal Behaviour 32: 1216-1224.

Hinde, R.A. (1953). The conflict between drives in the courtship and copulation of the Chaffinch. Behaviour 5: 1-31.

Hurd, P.L. \& M. Enquist (2001). Threat displays in birds. Canadian Journal of Zoology-Revue Canadienne De Zoologie 79: 931-942.

Johnstone, R.A. (1996). Multiple displays in animal communication: 'Backup signals' and 'multiple messages'. Philosophical Transactions of the Royal Society of London, Series B 351: 329-338.

Kilner, R. (1997). Mouth colour is a reliable signal of need in begging Canary nestlings. Proceedings of Royal Society of London B264: 963-968.

Kilner, R. (1995). When do Canary parents respond to nestling signals of need. Proceedings of the Royal Society of London, Series B 260: 343-348.

Kilner, R. \& R.A. Johnstone (1997). Begging the question: are offspring solicitation behaviours signals of need? Trends in Ecology and Evolution 12: 11-15.

Kilner, R.M., D.G. Noble \& N.B. Davies (1999). Signals of need in parent-offspring communication and their exploitation by the Common Cuckoo. Nature 397: 667-672.

Krebs, J.R. \& N.B. Devies (1987). An Introduction to Behavioural Ecology. Blackwell Scientific Publications. London, viii+456pp.

Kumar, A. \& D. Bhatt (2001). Preliminary observations on displays and postures in Oriental Magpie Robin, Copsychus saularis. Journal of Bombay Natural History Society 98(1): 5-11.

Kumar, A. (2004). Acoustic communication in the Red-vented Bulbul Pycnonotus cafer. Anais de Academia Brasileira de Ciencias (Annals of the Brazilian Academy of Sciences) 76(2): 350-358.

Lange, H. \& O. Leimar (2003). The function of threat display in wintering Great Tits. Animal Behviour 65: 573-584.

Leonard, M.L. \& A.G. Horn (1998). Need and nest mates affect begging in Tree Swallows. Behavioral Ecology and Sociobiology 42: 431-436.

Leonard, M.L., A.G. Horn, A. Gozna \& S. Ramen (2000). Brood size and begging intensity in nestling birds. Behavioural Ecology 11: 196-201.

Leonard, M.L., A.G. Horn \& E. Parks (2003). The role of posturing and calling in the begging display of nestling birds. Behavioral Ecology and Sociobiology 54: 188-193 
Marler, P. \& J. Hamilton (1966). Mechanisms of animal behaviour. John Wiley and Sons, New York, 783pp.

Marler, P. (1961). The evolution of visual communication, pp. 96121. In: Blair, W.F (ed.). Vertebrate Speciation. University of Texas Press, Austin, xvi+642pp.

Martin, G.R. \& S.R. Young (1983). The retinal binocular field of the Pigeon (Columba livia): English racing homer. Vision Research 23: 911-915.

Martin, G.R. (1986). The eye of a passeriform bird, the European Starling (Sturnus vulgaris): eye movement amplitude, visual fields and schematic optics. Journal of Comparative Physiology A 159: 545-557.

Martin, G.R. \& G. Katzir (1999). Visual field in Short-toed Eagles Circaetus gallicus and the function of binocularity in birds. Brain Behaviour and Evolution 53: 55-66.

Martin, G.R. \& H.C. Coetzee (2004). Visual fields in hornbills: precision-grasping and sunshades. Ibis 146: 18-26.

Martin, G.R. (2007). Visual fields and their functions in birds. Journal of Ornithology 148 (Supplement 2): 547-562.

Martin, G.R. (2009). What is binocular vision for? A birds' eye view. Journal of Vision 9(11): 1-19.

Masatomi, H. (2004). Individual (non-social) behavioural acts of Hooded Cranes Grus monacha wintering in Izumi, Japan. Journal of Ethology 22: 69-83.

McFarland, D. (1993). Animals behavior: Psychobiology, ethology and evolution, $2^{\text {nd }}$ edition. ELBS, The Bath Press, Avan, 585pp.

Møller, A.P. \& J. Erritzøe (2010). Flight distance and eye size in birds. Ethology 116(5): 458-465.

Murphy, T.G. (2006). Predator-elicited visual signal: why the Turquoise-browed Motmot wag-displays its racketed tail. Behavioural Ecology 17: 547-553.

Myers, P., R. Espinosa, C.S. Parr, T. Jones, G.S. Hammond \& T.A. Dewey (2008). The Animal Diversity Web (online). Accessed February 02, 2010 at http://animaldiversity.org

Petrie, M., T.R. Halliday \& C. Sanders (1991). Peahens prefer peacocks with elaborate trains. Animal Behaviour 41: 323331.

Price, K. \& R. Ydenberg (1995). Begging and provisioning in broods of asynchronously-hatched Yellow-headed Blackbirds nestlings. Behavioural Ecology and Sociobiology 37: 201208

Price, K., H. Harvey \& R. Ydenberg (1996). Begging tactics of nestling Yellow-headed Blackbirds, Xanthocephalus xanthocephalus, in relation to need. Animal Behaviour 51: 421-435.

Randler, C. (2006). Is tail wagging in White Wagtails Motacilla alba, an honest signal of vigilance? Animal Behaviour 71: 1089-1093

Randler, C. (2007). Observational and experimental evidence for the function of tail flicking in European Moorhen Gallinula chloropus. Ethology 113: 629-639.

Reebs, S.G. (1986). Sleeping behaviour of Black-billed Magpies under a wide range of temperatures. Condor 88: 524-526.

Rowe, C. (1999). Receiver psychology and the evolution of multicomponent signals. Animal Behaviour 58: 921-931.

Rowe, C. \& T. Guilford (1999). Novelty in a multimodal warning signal. Animal Behaviour 57: 341-346.

Sankaran, R. (1996a). Aerial display of Lesser Florican Sypheotides indica (J.F.M.), pp.185-197. In: Daniel, J.C. \& G.W. Ugra (eds.). Petronia: Fifty Years of Post-Independence Ornithology in India: A centenary Dedication to Dr. Salim Ali, 1896-1996. Oxford University Press, Delhi, 2003, 386pp.

Sankaran, R. (1996b). Territorial display of Bengal Florican. Journal of Bombay Natural History Society 93(2): 167-177.

Saunders, D.A. (1979). The biology of the Short-billed form of the White-tailed Black Cockatoo Calyptorhynchus funereus latirostris Carnaby. PhD. Thesis, University of Western Australia.
Sol, D., S. Timmermans \& L. Lefebvre (2002). Behavioural flexibility and invasion success in birds. Animal Behaviour 63: 495-502

Tinbergen, N. \& A.C. Perdeck (1950). On the stimulus situation releasing the begging response in the newly hatched Herring Gull chick (Larus argentatus argentatus Pont). Behaviour 3: 1-39.

Vijayan, V.S. (1978). Breeding biology of Bulbuls, Pycnonotus cafer and Pycnonotus luteolus (Class: Aves, Family: Pycnonotidae) with special reference to their ecological isolation. Journal of Bombay Natural History Society 75: 1090-1117.

Wellmann, A.E. \& C.T. Downs (2009). A behavioural study of sleep patterns in the Malachite Sunbird, Cape White-eye and Fan-tailed Widowbird. Animal Behaviour 77: 61-66.

Welty, J.C. \& L. Baptista (1988). The life of birds. Saunders College Publishing, USA, 698pp.

Zuk, M., J.D. Ligon \& R. Thornhill (1992). Effects of experimental manipulation of male secondary sex characters on female mate preference in Red Junglefowl. Animal Behaviour 44: 999-1006.

Acknowledgements: I am grateful to the Director, ZSI, Kolkata, for encouragement and the Officer-in-Charge, APRC, ZSI, Itanagar, for extending departmental facilities during the last phase of work. I am grateful to Director, WII, Dehradun for encouraging and extending to me Institutional facilities (during the second phase of the work) and Prof. Dinesh Bhatt, Gurukul Kangri University, Haridwar for guidance/ suggestions during the study and two anonymous reviewers for helpful comments on the manuscript. I am thankful to Dr. D.K. Sharma, Dr. Asghar Nawab, Dr. Ajeet Singh, Dr. Romesh Kumar Sharma and Dr. Ashish Kumar for their cooperation at various levels during the study. Financial support (during second phase) from DST under SERC Fast Track scheme (Project no. SR/FTP/LS-166/2000) is also gratefully acknowledged. 